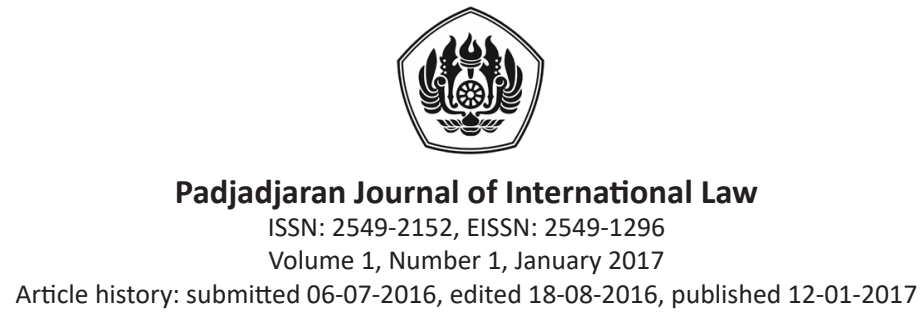

\title{
Responsibility to Protect: A New Form of Humanitarian Intervention?*
} Irawati Handayani*

\begin{abstract}
Human rights issues have become a common topic that continuously being discussed around the world. The major concern of international community on the protection of basic human rights leads to a challenge for the nation state to fulfill its commitment to protect the basic rights of their people from the possibility of harm that comes from internally or externally. Meanwhile, the principle of mutual understanding and respect among states and non-interference to domestic affairs of particular state has been generally recognized as the main principle in international law. Sometimes, a conflict that occurred inside a state, which is theoretically becomes a domestic issue, could be escalated and become a mutual concern of international society. When a human right violation occurred inside a state, ideally international community can not only 'sit and watch'. Especially when the violations are classified as grave breaches of human rights. The world community has a moral obligation to offer an assistance and search a solution to end that violations.

It is cleary noted that Article 2 (4) and Article 2 (7) United Nations (UN) Charter should not be regarded as an absolute prohibition of interference. Those articles are the limitation so that the intervention should not endangered territorial integrity, political independence and not contrary to the purposes of UN. However, the territorial integrity would be broken if the state lose their territory permanently, and in the context of humanitarian intervention there is no taking over a territory, since the main purpose is only to restore the condition as a result of human rights violation that occurred. Based on this assumption so intervention not contrary to UN Charter. One thing should be emphasized is that the requirements for intervention have to be very clear.

Following an unsettled debate on criterion of humanitarian intervention, a few years ago there were a new concept which is believed as an improvement or a 'new face' from humanitarian intervention. It called the doctrine of Responsibility to Protect. Generally, both of these concepts have similarity, especially with the main purpose on guarantee basic human rights and provide such protection when the authorized government is unable and unwilling to do so. However, the RtoP doctrine can not also avoid its controversy. The main discussion on this doctrine particularly questioning the legal status of this doctrine in international law and whether RtoP is only a new form of humanitarian intervention.
\end{abstract}

Keywords: humanitarian internvention, responsibility to Protect (R2P), duty to protect, non intervention, customary international law.

\footnotetext{
* The paper has been presented on the 5th CILS International Conference on International Cooperation, Faculty of Law University of Indonesia 27-28 October 2014, Jakarta Indonesia).

${ }^{* *}$ Lecturer at Faculty of Law Universitas Padjadjaran, Jl. Dipati Ukur No. 35 Bandung, irawati@unpad.ac.id, S.H. (Universitas Padjadjaran), LL.M. (Lund University), Dr. (Universitas Padjadjaran).
} 


\title{
Tanggung Jawab Melindungi : Bentuk Baru dari Intervensi Kemanusiaan?
}

\begin{abstract}
Abstrak
Isu mengenai HAM telah menjadi topik umum yang terus menerus didiskusikan diseluruh dunia. Perhatian utama dari komunitas internasional dalam hal perlindungan mendasar HAM selanjutnya menantang negara-negara untuk melakukan pemenuhan komitmen mereka agar melakukan perlindungan hak-hak mendasar dan tindakan yang dapat mengancam baik secara internal maupun secara eksternal. Sementara itu prinsip salaing pengertian dan penghargaan antar negara, prinsip non-intervensi dalam hubungan domestik telah diakui sebagai prinsip utama dalam hukum internasional. Kadang, konflik yang lahir di dalam negeri, yang secara teori adalah konflik domestik, dapat menjadi perhatian bersama masyarakat internasional. Pada saat terjadi pelanggaran HAM didalam suatu negara, seharusnya komunitas internasional tidak hanya 'duduk dan melihat'. Khususnya pada saat terjadi pelanggaran yang dikategorikan sebagai pelanggaran berat terhadap HAM. Komunitas negara mempunyai kewajiban moral untuk menawarkan bantuan dan mencari solusi untuk mengakhiri pelanggaran tersebut.

Seperti yang dijelaskan dalam Pasal 2 (4) dan Pasal 2 (7) Piagam PBB, pasal-pasal ini tidak dapat diangap sebagai larangan absolut intervensi. Pasal-pasal tersebut adalah pembatasan sehingga intervensi tidak membahayakan integritas wilayah, indpendensi politik dan tidak bertentangan dengan tuujuan PBB. Meskipun demikian, integritas wilayah dapat hilang apabila negara kehilangan wilayahnya secara permanen, dan dalam konteks intervensi kemanusiaan tidak ada pengambilalihan wilayah, karena tujuan utamanya hanya untuk mengembalikan kedaaan pada saat terjadinya pelanggaran HAM. Berdasarkan asumsi tersebut, maka intervensi tidak bertentangan dengan Piagam PBB. Hal lain yang harus diperjelas bahwa alasan intervensi haruslah jelas.

Mengikuti perdebatan yang tidak kunjung sellesai tentang kriteria intervensi kemanusiaan, beberapa tahun yang lalu dibuatlah suatu konsep yang dianggap sebagai wajah baru dari intervensi kemanusiaan. Secara umum, kedua konsep ini mempunyai kesamaan, terutama dengan tujuan utama dalam menjamin HAM dan menyediakan sejumlah perlindungan pada saat pemerintah yang berwenang tidak mampu dan tidak dapat memberikan jaminan HAM. Meskipun demikian, doktin RtoP tidak dapat terhindar dari kontroversi. Diskusi utama dari doktrin ini adalah pertanyaan tentang status hukum dari doktrin hukum internasional dan apakah RtoP merupakan bentuk lain dari intervensi kemanusiaaan.
\end{abstract}

Kata kunci: intervensi kemanusiaan, tanggung jawab untuk melindungi (R2P), kewajiban perlindungan, non intervensi, hukum kebiasaan internasional. 
Responsibility to Protect : A New Form of Humanitarian Intervention?

\section{A. Introduction}

State is a bearer of duty and rights in international law. In order to exercise its duty and rights, a state requires sovereignty. The sovereignty of a state is a vital element, necessary for a state to establish international relationship. An independent or sovereign state which already fulfilled the requirements for its establishment as dictated in The 1933 Montevideo Convention on Rights and Duties of States $^{1}$ should be considered to have an equal position with other states.

A sovereign state is one which has supreme power. Based on history, the word sovereignty was derived from Latin word superanus, means the topmost. According to Mochtar Kusumaatmadja, the space limiting such supreme power of a state is the borderline of the state itself. This means that the sovereignty of a state is confined only within its own area; its supremacy ends as soon as it hits the borderline to the sovereignty of another state $^{2}$. This limitation of powers signifies that the sovereignty of a state does not apply or stops as soon as it crosses the sovereignty of another state.

This principle of state's sovereignty is, in a way, in line with the non-intervention principle which has embodied in international law. The principle of non interference on domestic affairs of another state is the consequence of the formulation of the states as equal, as found in Article 2 (7) of the UN Charter. However, in the context of human rights law, it has been interpreted that states can no longer use non- intervention reasons against the repressive actions of a country towards its citizens or even against human rights violation conducted in a state of international concern. ${ }^{3}$ For example, if a state declared itself being bound to an international agreement concerning human rights while the agreement recognizes individual complaint, the filing of individual complaint by a citizen based on such agreement cannot be considered violation of domestic affairs.

It takes quite some time for international community to admit that widespread violence happening all across the globe require international attention. The supremacy of a state over its own internal, domestic affairs should not be allowed to justify such conducts of violence. Mass murdering, forced migration, sexual assault in great scale, and act of vandalism have been occurring for years since the beginning of civilization. The international society has gradually shown better concern on this matter, and real actions have been taken by international community since the World War II to protect every individual from violence, during either peace or war. However, it is not easy to unite the perception of every single member of international community in responding to the violence. Until the $21^{\text {st }}$ century, there has not yet been any agreement on the general mechanism to solve such issue.

The large number of the acts of violence happening all across the globe has drawn the sympathy of the UN as an international organization. As stated by Kofi Annan in the Millennium Report of the Secretary-General

\footnotetext{
${ }^{1}$ The requirement for establishment of a state based on Montevido Convention 1933 are: (a) a permanent population; (b) a defined territory; (c) government; (d) capacity to enter into relationship with other state. The first three elements has already accepted as general practice in international law and widely known as the doctrine of three elemets that formulated by George Jellinek by the end of 19 century (in Peter Malanczuk, Modern Introduction to International Law, 7th edition, London and New York: Routledge, 1997).

${ }^{2}$ Mochtar Kusumaatmadja and Etty R. Agoes, Pengantar Hukum Internasional, Bandung: Alumni, 2003, p. 18.

${ }^{3}$ Malcolm N. Shaw, International Law, 6th edition, UK: Cambridge University Press, 2008, p. 273.
} 
of the United Nations, 2000: "If humanitarian intervention is indeed an unacceptable assault on sovereignty, how should we respond to a Rwanda, to a Sebrenica-to gross and systematic violations of human rights that offend every precept of our common humanity?"

Kofi's statement spawned from the dilemma of whether the world should stand idly by the violation of human rights occurring across the globe. However, some efforts have been done since 1990, especially on the matter of gathering consensus of the world in order to respond to such violation of human rights which threaten individual freedom. Bernard Kouchner, a French Physicist, humanitarian activist, and minister, was the first to coin the idea of 'the right to intervene', which unfortunately did not attain the support of the states ${ }^{4}$. Despite this lack of support, a change was made in the practice of the UN's Security Council in the 1900s when conceptualizing humanitarian emergencies within a country that could rightly be considered as threatening global peace and security. This change was in the Resolution 688, April 51991 issued by the UN's Security Council. The content declared that the conduct of the Iraqi government against its own refugees was a threat against world peace. Thus, the resolution legitimated military action based on Article 2 (7) of the UN Charter. The Security Council urged Iraq to stop its violation against human rights in its own border and to agree on giving humanitarian support. This was the first time the Security Council of the UN ever recognized a repressing action of a state as a threat to global peace and security. ${ }^{5}$
A breakthrough did not appear until 2001 when the International Commission on Intervention and State Sovereignty (ICISS) offered a new concept of 'Responsibility to Protect' or RtoP declaring that nations or states have the duty to prevent and to respond to the violation of human rights in their respective borders. Less than four years after its conception, in the World Summit attended by the head of nations at General Assembly meeting, the RtoP concept was then formally introduced.

The concept of RtoP was expected to answer the question of how far actually can the Security Council as guardian of peace and security could carry out is duty, as well as to limit the intervention of states in the domestic affairs of a particular state. Among the reasons behind the formulation of this concept was the violation by countries of NATO against Yugoslavia in March, 1999. The violation was in the form of bombing, with the protection of the country's minority backing as the justifying reason. The conduct of NATO was quite controversial, as the bombing was without authorization from the Security Council of the UN, and no sanction has ever been taken.

In this article, the author would discuss the issue of humanitarian intervention in its relation with basic principles of international law: non-intervention principle. It is clear that the sovereignty of a state should be protected from the intervention of other states, which has become a principle recognized by states around the world. It, however, spawns an issue: Is the concept of humanitarian intervention

\footnotetext{
${ }^{4}$ Gareth Evans, The Responsibility to Protect Ending Mass Atrocity Crimes Once and For All, Washington DC: Brookings Institution Press, 2008, p. 32

${ }^{5}$ Nicholas J. Wheeler, "The Humanitarian Responsibilities of Sovereignty: Explaining the Development of a new Norm of Military Intervention for Humanitarian Purposes in International Society" in Jeniffer M. Welsh (ed.), Humanitarian Intervention and International Relations, New York: Oxford University Press, 2006, p. 33.
} 
Responsibility to Protect : A New Form of Humanitarian Intervention?

now being used as a weapon for violating the sovereignty of states? Moreover, responding to the latest development in the promotion of the RtoP doctrine over humanitarian intervention has spawned a question: Is the concept applicable, based on its theoretical and practical aspects? And, what is the current legal status of this doctrine?

\section{B. Non-Intervention Principle as a Challenge for Humanitarian Intervention Doctrine in International Law}

The improving international relationship among nations in this era of globalization has made the world a 'smaller' place. The intensity of economic and socio-political relationship has made the issue concerning human rights develop quicker and become easier to detect. The internationalization of human rights has promoted the violation of human rights issue as a common concern of the international community to tackle the issue, and to provide effective and quick response to protect the victims.

Since its formation 1945, the UN has shown considerable amount of efforts in tackling issues concerning violation of human rights. Unfortunately, the efforts have been only effective for only numerous cases, the collective security initiated by the UN has failed to solve the issues of violations of human rights in Cambodia, Rwanda, Somalia, and other places.

When the UN or other regional security mechanism failed to prevent violation of human rights carried out within a particular country, the
International Community should not sit idly by such reality. This statement has naturally led to the formulation of 'humanitarian intervention'. It has been considered (although through heated debate) as an exception to the noninterventionprinciple as found in Article 2 (7) of the UN charter. This humanitarian intervention has to be distinguished with the ability of a state to protect its citizens in foreign countries. ${ }^{6}$

It is vital to distinguish between collective securities formed by the UN with regional mechanism like peace keeping, peace enforcement, or other missions by the UN peacekeepers whose nature is multilateral with humanitarian intervention developing far before 1945 which was more unilateral-a result of cooperation between the armies of several states to challenge another state on the basis of humanitarianism, democracy, or basic human rights.

As an illustration, consider a state $A$ conducts a violation of human rights or violation against international humanitarian law against its citizens in consistently or systematically. The supporters of the humanitarian intervention doctrine would agree on the basis of the international customary law to justify another state $B$ to take military action into the border of $A$, even without the permission of the state $A$, in order to protect the citizens of the state $A{ }^{7}$

This concept of intervention could simply be understood as an effort to participate or intervene with the domestic affairs of another country. Intervention could be defined as any external attempt from subject of international

\footnotetext{
${ }^{6}$ John O'Brian, Op. Cit., p. 685

${ }^{7}$ Lyal S. Sunga, “The Role of Humanitarian Intervention in International Peace and Security: Guarantee or Threat?", in Hans Kochler (ed.), The Use of Force in International Relations-Challenges to Collective Security, Vienna: International Progress Organization, 2006 p. 44 .
} 
law in international relationship that could affect an outcome of a particular issue happening in a sovereign state. In Black's Law Dictionary, intervention is defined as the meddling of a state with the affair in the border of another state by the use of threat or power.

Lauterpacht defines intervention as a interfering of a state into the domestic affair of another state with the good intention to preserve or to alter the condition, situation, or goods in the particular state. ${ }^{8}$ Meanwhile, Starke formulates three types of intervention done by a state towards another state:

1. Internal intervention, intervention done by a state towards the internal or domestic affairs of another state;

2. External intervention, intervention by a state towards the external affairs between two states. Ex: the involvement of Italy which supported Germany in the World War II;

3. Punitive Intervention, intervention of a state towards another state as a form of retaliation. ${ }^{9}$

In the typological division of intervention, Starke intends to make legal the intervention of a state towards the sovereignty of another state. Starke argues that there are some cases where intervention could be justified by international law. Those cases are: ${ }^{10}$

1. Collective intervention as regulated in the UN Charter;

2. To prevent interest, rights, and safety of the citizens of a state in another state;

3. Self-defense. If intervention is required immediately in case of armed attack. The requirements of such self-defense is that it is immediate, no other means are available, no time to reconsider;

4. Related to protectorate of its dominion;

5. If the intervened state is considered to have conducted a serious violation of international law.

Before being allowed to execute the exceptional rights, the states have to heed the primary duty as instructed in the UN Charter, so that, except the Charter instructs otherwise, the intervention should not develop into threat or violence against territorial integration or political freedom of any nations. ${ }^{11}$

The UN Charter has specifically accommodated the sovereign equality among states and forbidden the intervention towards domestic affairs of other states, as instructed in the Article 2 (1): "The organization is based on the principle of sovereign equality of all the members."

and Article 2 (7):

"Nothing contained in the present charter shall authorize the United Nations to intervene in matters which essentially within the domestic jurisdiction of any state or shall require the members to submit such matters to settlement under the present charter, but the principle shall not prejudice the application of enforcement measures under chapter VII."

The charter clearly specified that in international relationships there should be no intervention at all. Such regulation is supported by the Resolution of the General Assembly of

\footnotetext{
${ }^{8}$ Huala Adolf, Aspek-Aspek Negara dalam Hukum Internasional, cetakan ketiga, Jakarta: PT. RajaGrafindoPersada, 2002, p. 31.

9 J. G. Starke, An Introduction to International Law 3rd Edition, London: Butterworth \& Co Ltd, 1954, p. 89-90.

10 lbid.,p. 90.

${ }^{11}$ See Article 2 (4) Piagam PBB.
} 
Responsibility to Protect : A New Form of Humanitarian Intervention?

United Nations 2625 (XXV) issued on October 24, 1970, later formulated as the Declaration on Principles of International Law concerning Friendly Relations and Co-operation among States in Accordance with the Charter of The United Nations.

Inpractice, the principle of non intervention is often violated by states under humanitarian reasons. The humanitarian intervention of Iraq in 1991, Somalia in 1992, and Kosovo in 1999 are proofs that the doctrine is conducted by states in their international relationship. The legitimation of this humanitarian intervention is based on the interpretation of Article 2 (4) of the UN Charter. ${ }^{12}$ Article 2 (4) is not an absolute prohibition, rather it is a mechanism to limit intervention so not to violate territorial integrity, political independence, and the purpose of the UN. Territorial integrity means that a state loses its territory permanently; while in humanitarian intervention the intervening party does not take territories permanently. The intervention has only the purpose of restoring the condition regarding the fulfillment of human rights in a state. Every state with its respective citizens retains their political freedom. Therefore, by this assumption, humanitarian intervention does not violate the UN Charter.

Moreover, according to the classification of Starke, the doctrine of intervention is not fully prohibited. There is a hole in the mechanism of international law allowing intervention to happen. In Starke's classification, humanitarian intervention can be categorized into the last classification concerning state conducting violation against human rights. The conduct of systematic and structural violation of human rights by a state is considered a serious crime against international law. Meanwhile, according to Teson, there are several aspects considered normal in the international custom related with humanitarian intervention. First is concerning the use of force by a state against the domestic affair of another state. Second is concerning the humanitarian value to be used as justification of the use of force. ${ }^{13}$

It is clear that the context of humanitarian intervention points to different matter than that in the Article 2 (7) of UN Charter, due to the humanitarian basis to justify the intervention, not because of political or other kind of interests prohibited by international law. Humanitarian intervention, thus, could be defined as followed: "Humanitarian intervention is the intervention into the territorial state by another state or a collective of states... for the promotion or protection of basic human rights where the territorial state is perpetuating abuse or is unable to provide the necessary protection to its inhabitant."14

Holzgrefe also defines humanitarian intervention as:

"...the threat or use of force across state borders by a state (or group of states) aimed at preventing or ending widespread and grave violations of the fundamental human rights of individuals other than its citizens, without permission of the state within those territory force is applied." 15

\footnotetext{
12 Yoram Disntein, War, Agreesion and Self Defence, Second Edition, Australia: Cambridge University Press, 1994, p. 89.

${ }^{13}$ Eric Adjei, "The Legality of Humanitarian Intervention", Thesis, University of Georgia, 2005, p. 29.

${ }^{14}$ Beth Van Schaack and Ronald C.Slye, International Criminal Law and Its Enforcement: Cases and Material, 2nd edition, 2010, p. 291.

${ }^{15}$ J.L. Holzgrefe, "The Humanitarian Intervention Debate, "in JL. Holzgrefe and Robert O. Keohane , Humanitarian Intervention Ethical, Legal and Political Dilemmas, London, New York: Cambridge University Press, 2003, p. 8.
} 
From the above definition, it can be inferred that an intervention normally harms the sovereignty of a state, also intervention is often done through threat or the use of force. Meanwhile, humanitarian intervention utilizes humanitarian motive to justify itself, that it is necessary in order to protect people whose rights are violated by their own government. This motivation underlying humanitarian intervention is, among others, utilized in order to stabilize a situation resulted from a conflict. Humanitarian intervention is there to prevent bloodshed from two conflicting parties and to prevent war.

The doctrine of humanitarian intervention is also considered an exception towards the general principle of international law, which is the prohibition of the use of force in international relation. Humanitarian intervention should not be identical with military action carried out by a state to protect its people, recognized as a justification of self-defense in international law. Meanwhile, in order to be categorized as humanitarian intervention, intervention using force should have a humanitarian purpose, not only for the interest of a single party. Also, the one benefits from it should not the people of intervening state. ${ }^{16}$

The context of humanitarian intervention originated from the support for the doctrine of just war. St. Augustine was the first to propose the term just war and to mention the criteria to limit it. The concept was further developed by St. Thomas Aquinas by the end of 1200 s. ${ }^{17}$ Grotius argued in his Laws of War and Peace published in 1625 that the legal status of the use of force in international relation has to be based on appropriate motives or reasons to start a war. In his natural law theory, Grotius considered that the cause must be serious to justify the use of force. Also, all other measures must have been attempted before the option of war is to be considered.

In practice, during the 19th century, the intervention carried out by the western countries to protect the Christian and minority in the Ottoman Empire, was considered to have a humanitarian cause. ${ }^{18}$ Two situations representing the practices of humanitarian intervention after 1945 were the invasion of India to Bangladesh in 1971, and the humanitarian invasion of Tanzania to Uganda 1979. However, these acts of intervention were questioned in regard to them being practiced by humanitarian cause. The people of East Bengal and Uganda, India, and Tanzania deemed it undeserving to use the term humanitarian intervention for their acts. Instead, they propose right to selfdefense based on the Article 51 of UN Charter as their justifying platform.

The test for legality of intervention towards territorial integrity of a state based on humanitarian reasons shown in the case of the repressive act of NATO towards Kosovo in $1999,{ }^{19}$ which had sparked continuing debate on the issue of whether Article 2 (4) allows the

\footnotetext{
${ }^{16}$ Ibid., p. 45.

${ }^{17}$ First of all, individual is not allowed to start a war, instead it is on the authorized authority; secondly, the cause of war should be appropriate and proportional; third, the parties of the conflict have the same intention to resort to war and not based on illegitimate reasons.

${ }^{18}$ David Harris, Cases and Materials on International Law, seventh edition, London: Thomson Reuters (legal) limited, 2010, p. 777.

${ }^{19}$ Humanitarian intervention conducted by NATO was a reaction to governent of FRY against ethnic Albania (which is a majority of more or less $90 \%$ of population in Kosovo), an autonomy province of FRY that belongs to Serbia. The action taken by FRY was escalated resulting 45 civilians being killed in city of Racak in January 1999. The proposal of NATO submitted to FRY to withdraw its troops from
} 
Responsibility to Protect : A New Form of Humanitarian Intervention?

use of force in humanitarian intervention. The event has also created gap between the state members of NATO with China, Russia, and nonblock Countries. ${ }^{20}$

To prevent the irresponsible use of humanitarian intervention, a guide is necessary to determine the legitimacy of its conduct. The guiding principles of humanitarian intervention has been given to the General Assembly of UN by United Kingdom, to be used as reference by the international community. The important principles are as followed: ${ }^{21}$

1. Every intervention, according to its definition, is an acceptance towards the failure of prevention measures. An improvement on the system of conflict prevention is, therefore, necessary. The development of policy that could eliminate the factors of conflict is required;

2. Primary principle that the use of force is only the last resort has to be maintained;

3. The responsibility to stop ongoing conflicts essentially belongs to the state where the conflict occurs. If the said state lacks the means or measures to solve the conflict within its border, the international community can offer their help;

4. When facing serious human rights violation, while the system governing the state within which the problem occurs shows inability or lack of willingness to take actions, international community are allowed to intervene. Intervention towards the domestic affairs is a sensitive matter. Thus, a strong and convincing evidence that a serious human rights violation is happening is necessary to justify intervention;

5. The use of force has to be proportional in order to attain the humanitarian purpose, and its protocol of procedure must refer to the international law.

Every use of force has to be done collectively. There is no single state with the right to carry out intervention representing the international community as a whole.

This guideline proposed by United Kingdom appears to be a step forward to regulate the legitimacy of humanitarian intervention, by providing a high threshold and by specifically regulating the boundary of the parties exercising the intervention. It is expected that intervention would not carry ulterior political agenda. However, a stronger, more binding instrument that could accommodate this guideline has to be appraised by the international community, so that it could become a hard law to bind the states across the globe.

\section{Responsibility to Protect (RtoP): an Old Concept with a New Name?}

State has the primary responsibility to protect its citizen under any conditions. At times, the government could pose a threat for its citizens by conducting a serious act of repressions, or violation of human rights calling for international concern.

\footnotetext{
Kosovo has been declined by President Milosevic. Furthermore, NATO conducted air bombing for 78 days within Balgrade as the main target and other part of the FRY. That caused a lot of civilians being killed and hardly injured, but it succesfully resulted on the surrender of FRY. However, NATO had never given a clarification with regard to its use of force as well as its legal basis for conducting such military actions.

${ }^{20}$ Christine Gray, "The Use of Force and International Legal Order", in Malcolm D. Evans (ed.), International Law, New York: Oxford University Press, 2003, p. 595.

${ }^{21}$ Mr. Robin Cook, "Speech", United Kingdom Guidelines on Humanitarian Intervention Secretary of State for Foreign and Commonwealth Affairs, 19 Juyi 2002, in David Harris, Cases and Materials on International Law, seventh edition, London: Thomson Reuters (legal) limited, 2010.
} 
The concept of RtoP is a new approach for the protection of society from violation of human rights. The basic concept of R2P could be applied when a state could no longer or no longer wants to protect its citizens from violation of human rights that could result in the great loss of lives. In such case, the international community has the duty to protect and has the right to intervene justified by humanitarian reasons.

'Responsibility to Protect' is a principle in international relation whose aim is to prevent mass destruction, war crime, ethnic extermination, and crime against humanity. This principle declares that every state has the responsibility to protect its citizens from the four international crime as mentioned earlier. Also, international community has the responsibility to help the states unable to fulfill such duty. If, due to certain causes, a state is unable or lacks the willingness to protect its citizens, the responsibility to save and protect the human rights of the said state then falls to the international community.

The concept of RtoP has been formulated to solve dire problem of humanity. This concept was first proposed by The International Commission on Intervention and State Sovereignty (ICISS) formed by the government of Canada on September 2000. The formation of this commission was related with the controversy of NATO's bombing of Kosovo, and the statement of Kofi Annan about how international community should react to serious and systematic violation of human rights that could threaten humanity. In short, the commission describes is mandate as followed:

"Generallyto buildabroaderunderstanding of the problem of reconciling intervention for human protection purposes and sovereignty; more specifically, it was to try to develop a global political consensus on how to move from polemics-and often paralysis-towards action within the international system, particularly through the United Nations."

On December 2001, the commission published a report on the result of several consultations and findings. The commission basically proposes the acceptance of the RtoP concept-the responsibility of the international community to protect the individuals whose basic rights are threatened or violated. The report of the Commision argues that a state has the responsibility to protect its citizen's human rights. If it is unable or unwilling to fulfill this responsibility, for instance in the case of mass killing, its sovereignty is temporarily being suspended. In such cases, the responsibility to protect the citizens shifted to the international community. It might be said that the concept of Responsibility to Protect attempts to give solution the uncertainty of legitimacy of humanitarian intervention that still debatable in international sphere.

The ICISS report on RtoP gives an idea to re-conceptualize sovereignty as implying responsibility. Sovereignty was re-characterized from sovereignty as control to sovereignty as responsibility in both internal and external duties. As a result, sovereignty implies that state authorities have the primary responsibility to protect the safety and lives of its citizens. It also means that government officials are responsible internally to their people and externally to the international community.

The main idea brought by the ICISS report is the changing of term from 'right to intervene' into 'responsibility to protect'. At the core of responsibility to protect lies the assumption 
Responsibility to Protect : A New Form of Humanitarian Intervention?

that sovereignty does not constitute a right of a state against intervention from other states but also encompasses a state's responsibility to protect people under its control. It can be argued that a state can no longer hide behind the shield of sovereignty and claiming of nonintervention from other states in internal affairs, if it fails to protect their people under its jurisdiction from massive violations of human rights.

The report of ICISS divides the responsibility to protect into three sub responsibilities: the responsibility to prevent, to react and to rebuild. The responsibility to prevent consist of measures aimed to avoid massive human rights violations and highlight the importance of early warning mechanism and root-cause conflict prevention, as well as diplomatic, economic and military instrument to confine a conflict before it escalates. ${ }^{22}$ The responsibility to rebuild comprises responsibilities which arise after a conflict, particularly after a military intervention has been conducted and aims to support the sustainable development of a stable and safe society. The responsibility to react constitutes the normative core of the responsibility to protect. It applies when massive human rights violations occur in a state and that state is either unable or unwilling to protect its citizens. In this case, coercive measures short of military action should be taken, including diplomatic, economic or military sanction. However, military action should only be acceptable in extreme case of large scale loss of life or ethnic cleansing and when four criteria are met: (1) military intervention has to be motivated by the right intention; (2) they must be last resort; (3) they must be proportional; (4) there must be a reasonable chance of ending the suffering. ${ }^{23}$

In the 2005 World Summit, states finally, after a drawn-out debate, through their respective heads of government, agreed to accept the concept of R2P in the paragraph 138 and 139 of the World Summit Outcome Document. The two paragraphs explicitly mention that it does not only accept the RtoP concept, but also imposes new duty and responsibility for international community to protect its population from genocide, extermination of ethnics, and crime against humanity. This formulation refers to the international crime, and could rightly be considered a step forward from the ICISS Report which declares that in case of disaster where a state could no longer solve it alone without help of the international community, while human lives are at stake, it could rightly legitimate intervention from international community for humanitarian reasons. ${ }^{24}$

\section{Responsibility to Protect : Is It A Legal Norm?} Many law experts questioning whether the RtoP concept is a soft law, or merely a political norm. Even to consider the concept a replacement for the concept of sovereignty and humanitarian intervention still requires solid supporting arguments. Some experts even went as far as considering RtoP a political slogan. ${ }^{25}$ Many parties recommended that RtoP is promoted to be a principle of international

\footnotetext{
${ }^{22}$ International Commission on Intervention and State Sovereignty (ICISS), “The Responsibility to Protect" (December 2001), para. 3.1

${ }^{23}$ Ibid., para. 4.19, 4.32-43.

${ }^{24}$ Cristina Gabriela Badescu, Humanitarian Intervention and the Responsibility to Protect-Security and Human Right, New York: Routledge, 2011, p. 120

${ }^{25}$ Carsten Stahn, "Political Rhetoric or Emerging Legal Norm”, The American Journal of International Law, Vol. 101, No. 1 (Jan, 2007$)$, p. 99-120.
} 
law by the collective commitments of the states all around the world. Some parties even stated that there are new elements contained in RtoP, but rather owe its root to a wider ideology or to an existing, widely applied legal tradition.

The concept of RtoP is actually based on the existing international laws. Despite its recycled nature, it succeeds in redefining sovereignty as authority into sovereignty as responsibility. It packs a warning to states that the sovereignty they hold is not a sort of legitimacy, a 'ticket' for them to act as they please in their own border. Instead, states are supposed to protect and recognize the rights of its citizens. The emphasis is on the falling of responsibility to international community, should a state fails in carrying out its duty. Again, the weight of the responsibility is for the international community to share, rather than being upheld by a single particular state.

This concept of intervention has long been developing in the international law system, but it has never had a concrete law base. The UN Charter indeed allows restrictive use of force, only for the UN Security Council and act of selfdefense. However, in its practice, the prohibition of the use of force has often been breached by a state or a group of state. The RtoP concept legitimates the Security Council who holds the primary authority, with prevention, protection, and rebuilding as its main goals.

The concept of RtoP at first was challenged by developing countries apart from the major power. There was a worry that the concept became a legitimation for the developed states to conduct an intervention towards another state, under the guise of providing protection. On the other hand, there was also an optimism that this concept could strengthen the role of the Security Council, so that its legitimacy and credibility would improve. However, the failure of the Security Council to take action in Darfur case, for example, shown that it is not easy to implement this concept into practice.

Additionally, the mechanisms through which the RtoP can be implemented are consistent with existing international law. Paragraphs 138 and 139 of the World Summit Outcome Document identify four principal ways in which RtoP can be implemented, each of which is consistent with existing international law: (a) the primary responsibility rests with the State itself. This is the cornerstone of sovereignty; (b) the international community may provide assistance, such as capacity-building, mediation and diplomacy. Such assistance may only be provided at the request and with the express consent of the state concerned and is consistent with the state's sovereign right to make bilateral and multilateral agreements; (c) the UN Security Council might take measures in a manner consistent with Chapters VI , VII and VIII of the UN Charter, the General Assembly might make recommendations on the basis of Article 11 of the Charter, and other Organs of the UN might act in accordance with the Charter; (d) paragraph 139 of the World Summit Outcome Document explicitly envisages a role for regional arrangements. Such roles must be consistent with the charters, constitutions or guiding principles of the regional arrangement concerned and with the UN Charter. It might said that if we are comparing the concept of RtoP and humanitarian intervention, RtoP has stronger base in the international law, since it is adopted by the General assembly in its meetings and being exercised by the Security Council. ${ }^{26}$ 
Responsibility to Protect : A New Form of Humanitarian Intervention?

In addition, comparing humanitarian intervention and RtoP, it is quite obvious that the RtoP offer much more that only intervention. As mentioned earlier that the doctrine encompasses the responsibility to prevent, to react and to rebuild. It is quite clear that the doctrine is not emphasizing on the intervention itself. Rather it is also focusing on how to prevent the violations of human rights that might occured as well as the steps should be taken in order to restore the condition back into normal before the violations happened. The doctrine, indeed, give an important insight into the ways in which effective human rights protection can be established and maintained.

With regards to the question of the legal status of the RtoP doctrine, this article wants to present an option categorizing this doctrine as a source of international law, specifically the customary international law. Is this categorizing acceptable?

The customary international law is the second source of international law found in Article 38 (1) of the Statute of International court of justice as "an international custom, as evidence of a general practice accepted as law." International court of justice has established the international custom as a source of international law through some of its decisions, like in Nicaragua Case where stated that there are two elements of international law, the objective element (general practice) and subjective element (generally accepted as law or opinion juris, and in Asylum Case: Columbia v. Peru (1950) where the International court of justice described custom as "a constant and uniform usage, accepted as law." Often, the debate is on whether one condition is enough to be called customary international law. There must be a rate of repetition in a particular time period, which has served as reference to the International court of justice. ${ }^{27}$ However, it needs to be considered also that International court of justice declared this only in the context of Asylum case, which is: "The facts... disclose so much uncertainty and contradiction, so much fluctuation and discrepancy in the exercise of diplomatic asylum and in the official views expressed on various occasions... that it is not possible to discern... any constant and uniform usage, accepted as law". In the case, Victor Raul Haya de la Tore, the leader of the fail rebellion in Peru in 1948 gained protection in the Colombia Embassy in Lima, Peru. Colombia and Peru filed the case to the International court of justice on the matter of whether Colombia has the right to gain protection, or should Victor Raul be returned to Peru, or excommunicated from Peru. In other words, from this case, the failure to categorize a custom as a customary international law is not due to the rate of repetition, but rather due to the inconsistency in its practice.

In Asylum Case, the International Court of Justice could not mention the proper duration to categorize a condition as fulfilling the criteria of 'constant' and 'uniform'. The International Court of Justice has also presented the necessary proofs so that a repeated uniform conduct could be categorized as customary law. ${ }^{28}$ As an illustration, there is a possibility that a repeated practice like the honoring of high-ranked officer in the army of a neighboring country. The practice could not be considered as law, and is more proper to be defined as

\footnotetext{
${ }^{27}$ Peter Malanczuk, Akehurt's Modern Introduction to International Law, seventh revised edition, New York: Routledge, 1997, p. 49.

${ }^{28}$ Alina Kaczorowska, Public International Law, London: Old Bailey Press, 2002, p. 15.
} 
honoring. The important thing is to determine what aspect of a practice could be considered as customary law international. Basically, the thing to be fulfilled in order for a situation to be considered customary international law is the duration of practice, the uniformity and consistency of practice, acceptance of the practice as law, opinion juris sive necessitatis and the generality of the practice. ${ }^{29}$

The next question is, could RtoP could be categorizedas a new customary international law? The emergence of the RtoP concept has been widely recognized and discussed in international political discourses, especially on its legal status in international law. Can the RtoP concept be categorized as a customary international law? Has this concept become a customary norm? Does this concept show a conceptual shift in viewing sovereignty that would indirectly lead to the significant alteration of law? The concept of RtoP has been considered as emerging principle of customary international law in the report of ICISS. The High Level Panel Report ${ }^{30}$ also mentions that RtoP is an emerging norm. However, the World Summit Outcome Document mentions nothing about the legal status of the RtoP.

The first problem in determining R2P as emerging norm is the ambiguity of the concept itself. ${ }^{31}$ This concept does not only change along its development but also becomes ambiguous for trying to combine several theories and thoughts into a single concept.
When first developed by the ICISS, the concept of RtoP consisted of the conceptual change of sovereignty which tried to develop the criteria and operational principles for intervention. The RtoP concept attempted to combine legal, political, and moral norms. To form a single law by the combination of the three norms isa very difficult aim, even with the consideration of the possible variation of concrete structures of norms, with some legal norms being more open than others, and some legal norms being principles and not law. ${ }^{32}$ Not all aspects of law could rightly be constructed as legal duty and right. RtoP is formed as a comprehensive basic structure for the prevention and management of the severe violation of human rights. However, not all aspects of the RtoP concept could become legal norms.

If the concept of RtoP is narrowly interpreted and is focused on the specific duty of a state or international community to protect, take measures, and rebuild, then it is not easy to interpret it as legal norms. Duty and responsibility should be interpreted as two different legal concepts. However, it does not mean that RtoP has no normative element. In the context of international law, responsibility is used to assign the possible consequence due to violation of international obligation. The violation of international obligation is referred to a state, and the state conducting the violation has a duty according to international law. ${ }^{33}$ This duty stimulates the responsibility of

\footnotetext{
${ }^{29}$ Ibid., p. 16-19.

${ }^{30}$ Report of the high Level Panel on Threat, Challenges and Change: A More Secure World: Our Shared Responsibility, U.N. Doc. A/59/565 (Dec. 2, 2004)

${ }^{31}$ Mehrdad Payandeh, "With Great Power Comes Great Responsibility? The Concept of the Responsibility to Protect Within the Process of International Lawmaking", Yale Journal Of International Law, Vol. 35: 469, p. 481

32 Ibid, p. 482.

${ }^{33}$ Responsibility of States for Internationally Wrongful Acts, G.A. Res. 56/83, Annex arts.1-2, U.N. Doc. A/Res/56/83, (Jan. 28, 2002).
} 
Responsibility to Protect : A New Form of Humanitarian Intervention?

a state to stop violation and to provide remedy. RtoP could not be considered a responsibility derived from the concept of state responsibility. The term responsibility is not only used technically but also generally as a synonym of the word obligation. When the International Court of Justice delivered its decision on the Barcelona Traction $^{34}$ case, responsibility is defined equally as obligation. In some parts of the decision, the court recognizes responsibility in its technical form as found in the state responsibility. The use of this ambiguous term spawns an interpretation that RtoP could rightly considered as duty or duty to protect. The importance of the terminological difference between responsibility and obligation could be seen from how the U.S. rejected the proposal of Secretary-General Kofi Annan to accommodate responsibility of the international community in the World Summit Outcome Document. ${ }^{35}$

In different context, the term responsibility shows competence and duty. Article 24 (1) of the UN Charter imposes some responsibility for the Security Council of the UN to maintain world peace. Meanwhile in Article 13 (2) of the UN Charter mentions about the responsibility of General assembly. In the two articles, the imposed responsibilities are not interpreted as the extension of rights and duty of these two UN bodies, rather it shown the competence of them as elaborated by the two different chapters in the UN Charter.

If the concept of RtoP is to be evaluated on whether or not it could be considered a customary international law as codified in
Article 38 (1) of the Statute of International Court of Justice then whether or not it has fulfilled the two primary elements: state practice and opinion juris ${ }^{36}$ have to be examined. Considering the difficulty to identify these two elements, it should be clear that it is also difficult to see it in the context of RtoP. From one side, the emergence of a customary international law could be identified by seeing the statements of states or their agreements on that concept in the confinement of the UN. The verbal statement or resolution of an international organization could be considered as proof of the state practice and opinio juris. ${ }^{37}$ However, considering the ambiguity of the RtoP concept, it is very difficult to determine which aspect of the concept actually concerns the elements of customary international law. This is because the RtoP concept has undergone many substantial alterations during its development. Thus, the implementation of RtoP in practice becomes unclear.

The next emerging difficulty is related with the aspect of the practice by states or other international law subjects. When the RtoP concept consistsof several measures that could possibly be taken to prevent violation of human rights in a particular state, it should be easy to use it to identify the relation between the reactions of a group of states or international organizations in a particular case. For example, related with the case of Darfur, the issued resolution of the UN's Security Council is classified as a form of implementation of RtoP. However, in relation with the practical aspect

\footnotetext{
${ }^{34}$ Responsibility of States for Internationally Wrongful Acts, G.A. Res. 56/83, Annex arts.1-2, U.N. Doc. A/Res/56/83, (Jan. 28, 2002).

${ }^{35}$ Op.cit., p. 483.

${ }^{36}$ Seecases : Military and Paramilitary Activities in and Against Nicaragua (Nicaragua v. US), 1986 danNorth Sea Continental Shelf (FRG v. Netherland), 1969.

${ }^{37}$ LihatkasusLegality of the Threat or use of Nuclear Weapons, Advisory Opinion, 1996; Military and Paramilitary Activities in and Against Nicaragua, 1986; Fisheries Jurisdiction (FRG v. Iceland), 1974.
} 
of a state, can the measures taken by the UN Security Council be considered in line with such aspect? Furthermore, often the emerging problem is when a state or a group of states act without referring to RtoP, but rather conducts an intervention towards the sovereignty of other states (as with the case of Kosovo and NATO in 1999). Thus, when a state or a group of state imposes a sanction upon a state as a response to violation of human rights in that state, it could interpreted that the state or the group of state has implemented the concept of RtoP, which is the duty to act or to perform, or it could be said that the state or the group of state act on the basis of RtoP.

\section{E. Conclusion}

The basic differences between humanitarian intervention with the Responsibility to Protect that RtoP offer more comprehensive measures to respond such a violations of human rights. Not only the reactive action in form of intervention, instead it also emphasis on the prevention and rebuilding measures. These three methods that makes RtoP seen as an improvement for the humanitarian intervention that considered only emphasizing on 'reactions'. Moreover, constructing the concept of RtoP as customary international law is very difficult. This is because the concept of RtoP develops not in a period of absence of law, rather it grows within an existing law. The concept of RtoP concerns existing and recognized legal norms in international law, like the legitimacy of the Security Council based on the Article 39 of the UN Charter and based on Chapter VII of the UN Charter regarding severe violation of human rights. The legitimacy of this UN body is an integral part of the RtoP concept. Thus, if the RtoP concept is to be considered an emerging norm or even customary international law, it could be indirectly interpreted that the legitimacy of the UN Security Council goes only as far as customary international law or emerging norms.

In addition, with regard to the issues that have been discussed, the authors raise up several suggestion as follows; firstly: in order to avoid the abuse of humanitarian intervention, a guideline to determine the whether the measures are legitimate is required. Apart from the guideline issued by England, an international document issued by the UN is required to become a formal guideline of the states regarding humanitarian intervention, second and lastly: a clear boundary has to be established in regard to the implementation of RtoP concept, especially in facing severe violation of human rights in a particular state. This is necessary to avoid abuse of the concept by a group of states or even by the UN for hidden political agenda.

\section{References}

Books

Beth Van Schaack and Ronald C.Slye, International Criminal Law and Its Enforcement: Cases and Material, 2nd edition, Foundation Press, 2010.

Cristina Gabriela Badescu, Humanitarian Intervention and the Responsibility to Protect-Security and Human Right, Routledge, New York, 2011.

David Harris, Cases and Materials on International Law, seventh edition, London: Thomson Reuters (legal) limited, 2010.

Dinstein, Yoram., War, Agression and Self Defence, Second Edition, Cambridge University Press, Australia, 1994.

Evans, Gareth, The Responsibility to Protect Ending Mass Atrocity Crimes Once and For All, Brookings Institution Press, Washington DC, 2008. 
Responsibility to Protect : A New Form of Humanitarian Intervention?

Malcolm D. Evans (Ed.), International Law, Oxford University Press, New York, 2003.

Huala Adolf, Aspek-Aspek Negara dalam Hukum Internasional, cetakan ketiga, PT. Raja Grafindo Persada, Jakarta, 2002.

JL. Holzgrefe and Robert O. Keohane (Ed.), Humanitarian Intervention Ethical, Legal and Political Dilemmas, Cambridge University Press, 2003.

Kaczorowska, Alina, Public International Law, Old Bailey Press, London, 2002.

Kochler, Hans. (ed.), The Use of Force in International Relations-Challenges to Collective Security, International Progress Organization, Vienna, 2006.

Malanczuk, Peter, Modern Introduction to International Law, 7th edition, Routledge, London and New York, 1997.

Mochtar Kusumaatmadja and Etty R. Agoes, Pengantar Hukum Internasional, Alumni, Bandung 2003.

O’Brien, John, International Law, Cavendish Limited Publishing, Great Britain, 2001.

Shaw, Malcolm N., International Law, 6th edition, Cambridge University Press, UK, 2008.

Starke, J. G., An Introduction to International Law, 3rd Edition, Butterworth \& Co Ltd,London, 1954.

Welsh, Jeniffer M. (ed.), Humanitarian Intervention and International Relations, Oxford University Press, New York, 2006.

\section{Other Documents}

Carsten Stahn, "Political Rhetoric or Emerging Legal Norm", The American Journal of International Law, Vol. 101, No. 1 (Jan, 2007).
Eric Adjei, The Legality of Humanitarian Intervention", Thesis, University of Georgia, 2005.

Mehrdad Payandeh, With Great Power Comes Great Responsibility? The Concept of the Responsibility to Protect Within the Process of International Law Making", Yale Journal Of International Law, Vol. 35: 469.

\section{Legal Documents}

International Commission on Intervention and State Sovereignty (ICISS), "The Responsibility to Protect", (December 2001).

Legality of the Threat or use of Nuclear Weapons, Advisory Opinion, 1996; Military and Paramilitary Activities in and Against Nicaragua, 1986; Fisheries Jurisdiction (FRG v. Iceland), 1974.

Military and Paramilitary Activities in and Against Nicaragua (Nicaragua v. US), 1986 dan North Sea Continental Shelf (FRG v. Netherland), 1969.

Report of the high Level Panel on Threat, Challenges and Change: A More Secure World: Our Shared Responsibility, U.N. Doc. A/59/565 (Dec. 2, 2004).

Responsibility of States for Internationally Wrongful Acts, G.A. Res. 56/83, Annex arts.1-2, U.N. Doc. A/Res/56/83, (Jan. 28, 2002).

UN. GAOR, 63rd Sess., 99thplen. mtg. at 18, UN Doc A/63/PV.99 (July 24, 2009). 